П. І. Білоусенко

\title{
ПОХОДЖЕННЯ СЛОВОТВІРНИХ МОДЕЛЕЙ ОБСТАВИННИХ ПРИСЛІВНИКІВ У СХІДНОСЛОВ'ЯНСЬКИХ МОВАХ
}

Білоусенко П. І. Походження словотвірних моделей обставинних прислівників у східнослов'янських мовах.

Обгрунтовано синтаксичну природу походження словотвірних моделей обставинних прислівників в історії східнослов'янських мов.

Ключові слова: деривація, адвербіалізація, морфолого-синтаксичний спосіб, історичний словотвір, словотвірна модель, східнослов'янські мови.

Белоусенко П. И. Происхождение словообразовательных моделей в восточнославянских языках.

Обоснована синтаксическая природа происхождения словообразовательных моделей обстоятельственных наречий в истории восточнославянских языков.

Ключевые слова: деривация, адвербиализация, морфолого-синтаксический способ, историческое словообразование, словообразовательная модель, восточнославянские языки.

Bilousenko P. I. The development of the word forming models of the adverbial adverbs in the East Slavic Language.

The syntactic nature of origin of word forming models of adverbial adverbs in the history of east Slavic languages was substantiated.

Key words: derivation, adverbalization, morphosyntax way, historic word forming, word forming model, East Slavic Languages. 
У східнослов'янському мовознавстві в питанні про словотвір прислівників тривалий час не було посутніх розбіжностей: дослідники адвербіальних систем української, російської і білоруської мов вважали морфолого-синтаксичний спосіб панівним у поповненні цього класу слів, що було обгрунтовано в монографії О. М. Федорук-Галкіної «Прислівник у сучасній російській мові» (М., 1939). Пізніше основні ідеї цієї праці лише уточнювалися в деталях. Лінгвістична думка була зосереджена, головним чином, на вивченні процесу адвербіалізації, умов іiі виникнення, факторів, що сприяють цьому процесові та його наслідкам. Шляхом адвербіалізації творяться, головним чином, прислівники місця, часу, способу [6, с. 9].

Дослідники вказували й на те, що завершення процесу адвербіалізації характеризується тим, що прийменники (у прийменниково-іменних конструкціях), так само як і флексії (у формах слів різних частин мови), перетворюються на словотворчі афікси [1, с. 380; 16, с. 282]. Ю. Шевельов також підкреслював, «що в ролі наростків він (прислівник - П. Б.) найчастіше використовує ті морфеми (значущі частини слова), які в іменах правлять за закінчення» [21, с. 360].

3 огляду на це погляди вчених на традиційну словотвірну класифікацію прислівників зазнали певних змін. Зауважимо, що вже О. М. ФедорукГалкіна у згаданій праці, аналізуючи такі прислівники, як «ползком», «кувырком», «броском», припускає, що «вони, можливо, і не були ніколи іменниками, що це особливий вид підсилювального слова, утвореного від дієслова, i, ймовірно, «ползком» - було можливе при «ползать», так само як «ходуном» - тільки при «ходити» [19, с. 57]. Деякі прислівники ніколи не були відмінюваними іменниками», - підкреслював I. К. Чапля [20, с. 22]. У 60-х роках утверджується думка, що українська мова має в своєму складі досить багато (виділено нами - П. Б.) прислівників поза адвербіального походження [1, с. 386]. Морфологічний спосіб творення стає предметом серйозних досліджень. Вивчення широкого фактичного матеріалу показало: наявність слів-зразків послужила поштовхом до появи нових дериватів, прислівнику як лексико-граматичному класу слів притаманне й внутрішньоприслівникове словотворення, що здійснюється за допомогою префіксов і суфіксів [18, с. 9-10]. На основі морфолого-синтаксичного способу творення прислівників 3'являється новий спосіб - морфологічний [8, с. 29]. Дериваційний підхід до творення префіксальних і конфіксальних прислівників завойовує прихильників у східнослов'янському мовознавстві [див. 8 , с. $29 ; 16$, с. $282 ; 18$, с. $10 ; 5$ та ін.].

Кілька праць І. Ф. Мазанька, учня Ф. П. Філіна, [див. 10; 11; 12 та ін.] і його ж кандидатська дисертація «Творення прислівників у російській мові XI-XVII ст. (на матеріалі лексико-семантичних груп зі значенням просторової орієнтації)» (М., 1977) становлять суто дериваційну 
концепцію творення обставинних прислівників. Дисертант стверджував, що «традиційна морфологічна класифікація прислівників давньоруської мови неповна», що «п’ять іiі розрядів (прислівники, утворені від іменників, прикметників, числівників, займенників, дієслів - П. Б.) не відображають найважливіших способів творення прислівників» [10, с. 123]. Проаналізувавши писемні пам'ятки, близькі чи ідентичні за змістом, у яких виявилося співвідношення за формою і за значенням безпрефіксних і префіксальних прислівників, дослідник дійшов висновку, що префіксальні адвербативи утворилися від первинних прислівників шляхом приєднання до останніх префіксів [10, с. 112]. І. Ф. Мазанько, зокрема, зауважував, що посторонь «поряд, біля, обіч» походить не від іменника сторонь, як вважалося раніше, а від прислівника сторонь, адже, за даними пам'яток, сторонь - прислівник [Там само с.117]. Таким способом, на думку цього мовознавця, утворено прислівники впереди(t), доныне, додьньсь, вночь (вночи) i багато інших. Зрештою, І. Ф. Мазанько заявив, що «процес творення прислівників за словотвірними моделями $\epsilon$ не переродження чи переростання адвербіалізації в деривацію, а закономірний розвиток словотворчих процесів всіх історичних стадій мови» $[11$, с. 2], унаслідок чого деривація стала «одним із найбільш продуктивних способів творення прислівників» [10, с. 124]. «Якщо навіть існують схожі на прислівники синтаксичні конструкції, то до творення прислівників вони не мають ніякого стосунку, оскільки прийменниково-відмінкова форма не переходить у прислівник, не прагне до адвербіалізації й не розвивається в цьому напрямку. Прислівники творяться дериваційним шляхом» [10, с. 115].

Наші спостереження показують, що справді, у найдавніших східнослов'янських пам'ятках уживалися безпрефіксні прислівники адвербіалізовані форми різних відмінків іменників та прикметників типу верхъ «вверх», перекъ «впоперек», вечеръ «увечері», ночь «вночі», утро «вранці», осень «восени», гор $\mathbf{t}$ «вгорі», низъ «вниз», низоу «внизу», л $\mathbf{k} m \mathbf{t}$ «літом», весн « «весною», верхоу «вгорі», перво «спочатку, щойно», долоу «додолу», дол « «внизу», далече, давно, долго, ближе тощо, наприклад: звз ъда виса ... гор ъ (XI/XIII-XIV XА 17); низъ пасти с колесніцуа (203); оузряии много ... Фмраченья деневное и тыгости телеснь долу и гор ист жкающимъ (245); бг̃ на нбоси выспри и ты на земли низоу (313); далече (1076 СДЯ II 423); перво насъ гоубити (к.ХІІ/бл.1425 ЛК 297); бории стощуе

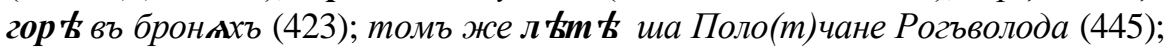
Изаславь поиде своими полкы гор н на броды (448); гор в верху написано есть (1106-1108 ХД 9); теремецьь ... верху кругомь (10); есть м тсто на земли дол t (31), пор.: Он же съвръже ю долу (III/XV КП 34); в tсн tжже бывии ... поидоста на НАтвез 中 (1213/бл.1425 ЛГВ 776) тощо.

Дійсно й те, що панівна більшість цих форм пізніше була замінена 
префіксальними чи конфіксальними дериватами, i хоч процес заміни розпочався в найдавніші часи, безпрефіксні форми нерідко фіксуються пізнішими українськими пам'ятками, а частина 3 них функціонує в діалектах і досі, пор: $и$ вид $\mathbf{k} в$ люди издалеча Алељандрь (XI/XIII-XIV ХА 45); ибо Июдтска жизни не изнизоу имаше начальстви всл (289); ускоре бысть разрушиль Уркана (XI/XVI ИФ 181); хот қхом б қжати вънизъ (XIII/XV КП 10); се бо исперва списавшу (20); и при қхаша Половци напередъ (к.ХІІІ/бл.1435 ЛГВ 802); до Пєр४нова Д8ба гор Скломь (1302 П 19), пор. горі «уверх, вгору, нагору» (Піпаш 38), «вгору», (Негрич 52), горі йсти вєчєръ и рано (др. пол. XVIII КЛ 105); $\omega(m)$ того

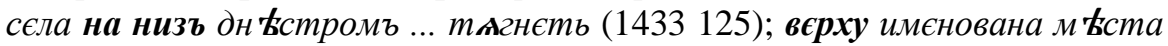
(1437 136); сверха выписана села (1451 159); лете (XV ССУМ I 554); zop t(1375 ССУМ I 254) тощо.

Це саме спостерігаємо в історії російської мови: пожня ...от ивовъго куста верхъ до коньцуь логу (XV СлРЯ ХІ-ХУІІ II 101) «вгору», пор. сучасне вверх; оживе, аки сонце огряявще весне (XVI Там само 114); перстьл два сложиши ... и подъяиа горь (1682 IV 79) «вгору»; Поликарпь долу главу поник (1691 IV 295) «вниз»; Любо низъ под. холмом или под. камениемь (XVI XI 368) «вниз»; Мощуно вамь есть зд низу на земли промысль и помощзь обр қсти (1674 XI 375). Безпрефіксні форми збереглися й у сучасних російських діалектах: Рыба-та ночью верх идет (Арх III 129) «наверх»; Низ головой (СРНГ, 21, с. 224) тощо.

Безпрефіксні форми прислівників документуються на різних етапах розвитку білоруської мови та в сучасних білоруських діалектах: низу «знизу» (1516-1519 ГСБМ XX 398), весне «весной» (к. ХНI - поч. XVII III 146); Ночь при ночь вартуем (Нос I 342); Косцьь в горл қ перекъ с 104); Долі гарячок пастаў, лі печьл (Ян 106) та ін.

Однак запропонований I. Ф. Мазаньком дериваційний підхід до вивчення прислівника не дає відповіді на суттєве питання: чим викликаний процес деривації, тобто яке значення (чи його модифікацію) вносив префіксальний елемент у новостворений прислівник. Вказівка на мету словотворчого акту має вивести на передній план у вивченні словотворення його семантичний аспект [23, с. 252].

До того ж згаданий підхід не давав відповіді на питання про походження словотвірних моделей прислівника. Цю проблему було порушено в книзі О. І. Янович «Наречие в истории русского языка: Генезис и функционирование основных морфологических типов производных наречий» [24] та деяких їі статтях. Прислівники, які утворені шляхом адвербіалізації, дослідниця відносить до ядра морфологічного типу; прислівники ж, утворені за відповідними моделями (вторинні прислівники), перебувають на периферії певного структурного типу. Ядро і периферія, 
таким чином, розрізняються у згаданій праці не за ступенем продуктивності, a за походженням. I. Ф. Мазанько підкреслював, що прийменники не можуть самостійно поєднуватися 3 прикметниками $[11$, с. 12], і на цій підставі виключав можливість адвербіалізації сполучення прийменника i прикметника. О.І. Янович обстоює думку про творення прислівників типу вскор $\mathbf{k}$, вмал $\mathbf{k}$, порану, отъдалеча із словосполук в скор $\mathbf{k}$ вр $\mathbf{k} и е н е$, по рану времени, оть далеча пути тощо в результаті згортання атрибутивно-іменних словосполучень 3 наступною адвербіалізацією форми субстантивного прикметника [див. 24, с. 8-9], а, отже, й утворення відповідних адвербативних моделей.

Давню ідею лексико-семантичної конденсації [див., зокрема, 25] O. I. Янович обгрунтувала на великому фактичному матеріалі. Для цього багато вихідних форм (неконденсованих словосполучень) було штучно реконструйовано. Зрештою, ця позиція, як така, що вже відстоялася в науці, потрапляє в підручники 3 історичної граматики російської мови [див., наприклад, 7, с. 366-367]. Проте все розмаїття префіксальних чи конфіксальних прислівникових форм української мови важко звести до «неконденсованих словосполучень», хоч характер синтагматичних зв'язків (виразний інколи і в сучасній мові) неконденсованих словосполучень, що існували паралельно 3 ізосемантичними прислівниками, безумовно впливав на морфологічне оформлення останніх.

Спостереження над прийменниково-відмінковими конструкціями й прислівниками, що мають однозвучні з прийменниками префікси, дозволяє стверджувати, що традиційні погляди на природу i сутність творення словотвірних моделей прислівника загалом у своїй основі не були хибними. Зокрема, жоден прислівник розгляданого типу не має префікса чи препозитивного елемента конфікса, який не був би однозвучний 3 прийменником. До того ж на походження обставинних прислівника вказує їхня природа. «Включення окремих слів, форм слів i синтаксичних сполучень у ту чи ту мовну групу завжди зумовлено їхньою функцією» зауважував Пауль [див. 15, с. 278]. Такою функцією для прислівника 3 самого початку його виникнення було виконання ролі обставини $[17$, с. $120 ; 7$, с. 364 та ін.], що спостерігається на всіх етапах формування цієї категорії слів [див. 13, с. 377; 2, с. 306; 7, с. 364 та ін]. Ця вагома деталь дала підстави І. Р. Вихованцю цілком резонно назвати розгляданий клас слів обставинником [3, с. 7]. 3 обставинним значенням могли виступати як окремі слова - безприйменникові відмінкові форми імені, так і сполучення повнозначних слів (дыньсь, сегодня, топерво «щойно» тощо) чи прийменниково-відмінкових словоформ. Зауважимо, що в синтаксисі східнослов'янських мов протягом останньої тисячі років спостерігається процес бурхливого зростання кількості прийменниково-відмінкових форм, які в багатьох випадках замінили обставинні безприйменникові 
конструкції [22, с. 92; 14, с. 214; 9, с. 47]. Прийменниково-відмінкові конструкції були формально виразнішими, ніж безприйменникові [див. 14, c. 214], вони більш точно й диференційовано передавали думку. Саме завдяки адвербіалізації прийменниково-відмінкових форм іменника 3'явилося в мові багато прислівників типу вниз, уверх, вкруг, вночі, додолу, зночі, увечері, навесні та багато інших.

У постприйменниковій позиції 3 давніх часів, крім іменників, закономірно могли виступати окремі субстантиви-займенники: пр қж(д)е законъ. ти по томь блгг(д)ть (1037-1050 ІлСл 79); первое поб қгоша Поршане. пото(м) Изаславъ (к.ХІІ/бл.1425 ЛК 382); По томь ... создахъ и(е)рк(о)вь (XII/XIV УВ 23). Прийменники ж, як відомо, є засобом вираження залежності іменника (чи його еквівалента) від інших слів у реченні. Проте побудова значної частини прийменникововідмінкових конструкцій наштовхувалася на відсутність субстантивів (іменників, займенників) 3 потрібними для мовця в конкретній ситуації значеннєвими параметрами.

Необхідна семантична ідея могла міститися в прислівнику, тому досить часто роль іменника виконували адвербативи: юна же свыше низъ идаше (XI/XIII-XIV XА 56); И отвсюду обишедше, избиваху жидь (XI/XVI ИФ 179), пор. и. поткоиа на нь вси ... ЛК 432); испьтахь добр ты оть сущчихъ mу издавна (1106-1108/XV ХД 10); извну написана хитро (15); и есть кладязеть и до днесь подъ горою тою (34); съ заоутра и до вечера (к.ХІІ/бл.1425 ЛК 359), пор. съ завтри же с вде в немь (295); и

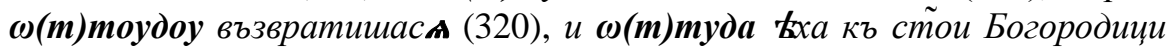
(403); Изаславъ поиде потиха южида брата своего (357); издалеча. есми по кхали (379); не был(с) помочи ему ни с(т)куду же (445); кр(с)ть и донын ' стоить (ХІІІ/бл.1425 ЛГВ 732); вогнаша и в гра(д) Белзъ. и за мало города не взаша (745); оть юны врьсты дозд изведет тя отсюду (33) та ін. Варто звернути увагу на те, що в постприйменниковій позиції прислівники поводять себе як іменники, вони набувають форму іменника, а різнобій у фіналях пояснюється тим, що мовці мають справу з незвичними субстантивами, у яких по-різному визначають рід, а значить і закінчення, яке стає суфіксом.

Потрібна мовцеві семантика могла міститися в інших частинах мови, що стало передумовою творення субстантивів зі спеціалізованою функцією: виступати в постприйменниковій позиції обставинних прийменниково-відмінкових конструкцій. Ці субстантиви могли мати як віддієслівне, так і відприкметникове походження.

Віддієслівні прислівники. Іменники зі згаданою спеціалізованою функцією, хоч і нечасто, але траплялися вже в пам'ятках давньокиївської 
доби, наприклад: б $\mathbf{z}$ бо рать велика бес перестани (1118/1425 ПВЛ 127); бъ бо уже в заморозъ (142); Галичане изоимама излслави(ч) на розгон $\mathbf{6}$ (к. ХІІ/1425 ЛК 464); бнъ же в отороп ' (ін.сп. въ mopon t) выскочивъ по нихъ (587); Романъ же слишеть без опаса к моужемъ Галичькимъ (660); и оудариша на росв $\mathbf{k m}$ t по нихъ (677) (пор. російське рассвет) та деякі ін.

Відприкметникові прислівники. У цих прийменниково-відмінкових конструкціях постприйменникові компоненти традиційно, навіть в найновіших дослідженнях [див. 5], вважають ад’єктивами. Однак уже в українській мові давньокиївського періоду прийменник не міг поєднуватися з прикметником у принципі, оскільки прикметник давно вже відмежувався від іменника й виступав окремою частиною мови 3 притаманним йому лексичним значенням, граматичними характеристиками, а прийменник за визначенням поєднується лише 3 іменниками. Тому постприйменникові компоненти в конструкціях типу изънова, направо, помалу, въскор $\mathbf{k}$, въборз $\mathbf{z}$ і под. не є прикметниками, наприклад: $O$ моиси, како проведе

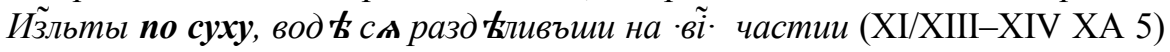
«по сухому місцю», cyxy - це іменник неповної парадигми, який утворено від прикметника сухьи, він тут виступає в місцевому відмінку й закономірно має закінчення іменників новостворюваної другої відміни, пор.: ходихъ по морю и по въздуху (XII/XIV СДЯ VI 442), пор. они же ... извлекоша на сухо мрежу (ХД 51), банкою насухо по плєчохъ ставить (1759-1775 ЛО 51); Възбернин $\omega$ первыхъ словесехъ въпрост $\mathbf{6}$ (XI/XIIIXIV XА 5); познанть ли на долз' оу кого купивъ (XI/1282 ПР 125); яко хощеть измлада Б(ог)у датися (XIII/XV КП 22) «з молодих літ», іменник млада, що тут ужитий у родовому відмінку, утворено від прикметника младъ, пор. въ поустиню въселисл измлади $\omega(m)$ пеленъ сам $\mathbf{k} x$ (XI/XIIIXIV XА 226); Т 172), пор. И помале в всть бысть, яко Антигонь убьень бысть (там само); и ту есть на Великое море внити, на шює въ Іерусалимъ, а на десно къ Свят тй Гор t (1106-1108/XV ХД 3) (июии, десный); подобенъ Іорданъ къ

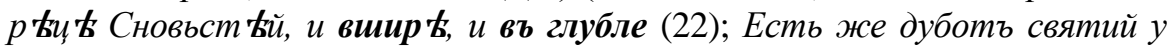
пути на близу (34); И доидохомъ по здраву до святого града (39); и есть оть моря подале Антіохіевъ градъ (44); И ест пещерка та вдал' оть Преображеніа (55); Женою сперва прад $\mathbf{b}$... изъ рая изгнанъ бысть

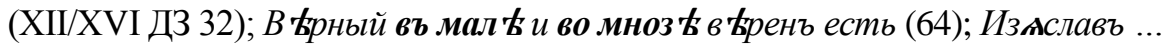
nо kxa в борз t с полком своимъ къ Переславлю (к.ХІІ/бл.1425 ЛК 311); оувороти кона на право (349); и до сыти ми пересерди (366); по л ъвоу Вачьслава и Изаслава. Фли до Ллдьскихъ вороть (427); стама ИзАслава по праву (427), идоущоу емоу по ровни (ХІІІ/бл.1425 ЛГВ 767) тощо.

Зароджена в надрах давньоруської доби, ця тенденція особливого розвитку набула в українській мові наступних століть. Будівельним 
матеріалом для розгляданих конструкцій продовжують вряди-годи використовуватися займенники: надъто (1322 ССУМ II 13) «крім того, до того(ж)»; Лишнє: ... назбы (m), надто (1627 БерЛекс 59); потьмы, затылмъ (1643 Грам 50) та деякі ін.

Досить активно в ролі субстантива в прийменниково-відмінковій формі виступають адвербативи: которыи теперь мають и напотомь набудуть (1398 П 103); отдавна (1475 ССУМ II 101); a $\omega(m)$ того сто(л)па. у другїи сто(л)n щзо $\epsilon(\mathrm{cm})$ на юбочи (1488 Рус 125); вн $\mathbf{k}$ зв ४нтра, надвор ж, кром $\mathbf{t}(1627$ БерЛекс 16); изв встнш: запєвнє, достатєчнє, допєвна, и бєзпєчнош (45); по(д) рейментарскіе ноги навсегда мя пове(р)гаю (1716 ДНМ 89); придай яго(д) ...з(ъ)груба притолчєни (x) (1759-1775 ЛО 20); усмажъ яєчє(н)ку зр ъдка (50); Кто шалвию из виномь оуживаєть, то звнутръ болачки не ростуть ан $\mathbf{6}$ внутр $\mathbf{t}$ не пріникають (др. пол. XVIII КЛ 97); жівого ср ъбра лоть розотри на м клко (104); Зиирока (O I 323) «понад можливість; на широку ногу; марнотратно» тощо. При постприйменникових компонентах у різні часи могли 3'являтися означення, які є свідченням того, що ці компоненти мовці сприймають як субстантиви, наприклад: исъ (c)mapa давна ку свлтои корун 中 ... прислухають (1434 Р 130), пор.: з давнього давна, з давніх давен,

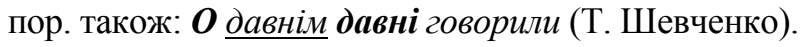

Прислівники одного й того ж значеннєвого типу можуть бути похідними відмінкових конструкцій з різними прийменниками, пор. вниз донизу, вгору - догори тощо. А оскільки процес творення прийменникововідмінкових конструкцій не позбавлений автоматизму, то вряди-годи замість використання готового прислівника мовці втягували цей же адвербатив в орбіту прийменниково-відмінкової форми як постприйменниковий елемент: бж(с)твьнымь соудомь поправд ь показани быма (XI/XIII-XIV XА 118), пор. заправды, поправде (Грам 1643 50), заправді (O I 310); падесл с престола навъсп жмть (ХА 121); за мало бо сего срацины не иа (520); и замало не нять бысть (XI/XVI ИФ 192); и есть м tcm вънезаап $\mathbf{x}$ потече источникъ (1054 ІлСл 89), пор. незапоу «неждано» (СДЯ V 274); о то оздано все комарами около (1106-1108/XV ХД 19); напотылм (1410 ССУМ II 23), пор.: на по тыл(м) хот mоту ... прода(mu) (1575 АО 53) «потім»; оувън 'тмръ (1495 ССУМ II 463), пор. во вну(m)рв нє потрєба ужсива(m) (тр.чв. XVIII ЛО 23); пром тнили есмо Селищу свое, ито ж намь не споручь, а Тушкелю споручь (1347 П 26); ознаймуємъ єдностайн в всмм и ко(ж)дому зособно (1401-1411 Рус 26), пор. зшсобна (Грам 1643 51), умы(с)льне его ... до козако(в) выправи(л) (1605 ДМВН 92), пор.: Майор перезирнувся з Толкуновим $і$ навмисне голосно зареготав (Р. Самбук); Знагла внєзапу вєсма б қхма (сер. або др. пол. XVII Син 119); Надаремне бєз ума всує тунє, всяко, // всяко 


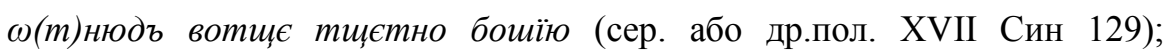
Потаємнє штай, тайн $\mathbf{t , ~ т а и н о ~ ( 1 4 6 ) ; ~ з а п р о с и в и и ~ . . . ~ н а ~ г о с п о д у ~ с в о ю ~}$ увосены (1711 ДНМ 55); з(в)особна те(ж) еще питали (1714 67); вътеки рушили (1719 96); пор.: Максим хотів кинутися навтьоки (Ю. Смолич); $з$ сус ъдомъ <..> из Сидоренковимъ хлопче(мъ) двома вози улягома (1719 ДНМ 104); И зале(д)во ... к себ ъ его привабиль (1719 109); не толко вдень але и уночи билися рокопаш (1720 ЛСам 70), пор.: Гвинтівки вони матроси тримали на руку - вони йшли вже вруковпаш на багнет; Гайдамаки знизу йдуть! Сила-силенна! Цепами! Нарукопаш! (з тв. Ю.Смолича); побіля (О II 85) «біля»; Попотемки (115) «потемки» та ін. Структури 3 надлишковими префіксами-прийменниками часто, видозмінюючись семантично, у значеннєвому плані знаходять свою нішу в адвербіальній системі української мови (пор. правда - справдi, просто спроста, неспроста, поки - допоки), можуть ставати елементами складніших префіксальних чи конфіксальних конструкцій.

У постприйменниковій позиції виступають переважно новотворидевербативи з нульовим суфіксом: без упроса (1480 ССУМ II 481); И зложиль рокъ в поруцє пятисо $(m)$ ко(n) грошє(u) (1584 АЖ 74); куля навылет прошла (84); наглая, по мусу утрата (1620 УП 166); рушиль на отс ъиь войску (до 1672 ЛСам 21); бвз в ъдома ... вашого (1711 Гетьм 49); почти на пролом (1720 ЛВел I 68); вплавъ пустишися (433); отпустить на поруки (1724 ЯМ 147); на пробу привезль гор қлки (155) де(р)жаль в запв(p)m 女 (1726 Гетьм 79); пл tнниковъ ... на окупь випустиль (1770 СИ 354); церкви ... въ откупъ такъ запродивали (371); погнал за Баввою в погонь (1788 Деркач 115); Якъ пишла земля въ роздиль, та стали рубать лисъ; Якъ пишла земля въ подиль, про Великий Лугъ и забулы (з тв. Я. Новицького); У мене люде не на убій (Ю. Федькович); не в забарі (Гр II 3); Взяти на спит (IV 175); Буває ... візьмуть тебе на вис міхи (Яв 98); з перепою богу душу оддав (О. Кониський); ... хоч би тобі один хвіст залишився на розвід (М. Стельмах); Обертайся, земле, без упину (Є. Плужник); Коні аставилис' без призору (Лис 173); продавати на заріз (O I 284); ... летять вони [журавлі] вдень і вночі без передиху, без єдиної зупинки; Інструктував при цзьому бійців детально, як наряд на розводi (з тв. О. Гончара) та багато ін. Постприйменникові компоненти в таких конструкціях можуть вступати в атрибутивні відношення 3 повнозначними частинами мови (без зайвого поспіху, на власний розсуд), що підкреслює їх субстантивний характер.

У різних за часом створення українських пам'ятках документуються також структури 3 відприкметниковими післяприйменниковими субстантивами: а потомъ, пустивъши Чижовку въ право, а въ лево Ретовъскою поступуючи ... ажъ ку Пруднику идучи (1322 П 21); по 
дробноу (1475 ССУМ II 168); направо (1491 23); соуполна (1493 402); однова (XV 76); потрезвоу (XV 215); наново (1500, 20); згола (1596 ЛексЗиз 27), пор. не м ъемъ з(ъ)гола чимъ ро(с)платися (1710 ДНМ 40); поблизу рым У (1627 БерЛекс 178); мы обоє квитуємо о(д) мала до велА (1579 АО 59); нал ъво (Грам 1643 49); По молодєцку, По простацку (сер. або др. пол. XVII Син 145); По просту (146); тот впрудце скоротится так же (1670-1696 IB 151); бвз в ъдома ... вашого (1711 Гетьм 49); м қли усов Һтовати, якимъ би способомъ войско задержати оть розезду врознь (1720 ЛВел I 132); Сина нашого ... на веселе $\mathbf{\text { дуучого ... хот } \mathbf { k } л и ~}$ розгромити (141); Ракочій, впредъ въ легц т пошовмій, умкнуль ... за гранииу (284); а иншихъ ... допрашиваль пороз(в)нь (1724 ДНМ 158), пор. ти(x) з(ъ)лодюгъ роз(ъ)вести нарозно (1740 280); р ъчъ слиха(в) (1752 326); Приступи, ияаренку, до близу, уклонись изарівні до низу (Гр I 73); Солдати рушили вллиб краӥни (Ю.Смолич). Другі компоненти таких конструкцій теж зрідка могли мати означення, пор. до останку - до самого останку, змалку - з самого малку.

Аналогічні процеси відбувалися в російській і білоруській мовах. Про це свідчать як історичні факти, так і дані сучасних літературних мов та діалектів. Зокрема, в мові російській могли творитися адвербативи від прислівників, наприклад: внов новь (XI XI 394) «те саме»; вново (1679 II 243) «наново, знову»; пор. ново (XI XI 396) «те саме»; вблизу стати от множества людей (1552 II

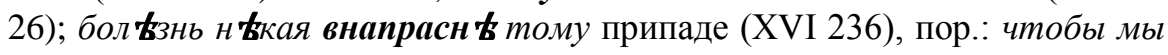
напрасн в в конецъ не погибли (1596 XI 236); вкратк' (вкратц $\mathbf{z}$ ) (1651 II 201) «коротко, небагатьма словами» співвідносне з кратко чи краткий; вблизи соболей н $\boldsymbol{k} т ь$ (Там само 1684 20); вверху (1614 29) «раніше, вище (про написане)» чи «у верхів 'і, біля джерела» (1671 29); У Федора пожни тут не было а чистил он то м ъсто не самое вдавни (1655 34); Море то вдавн $\boldsymbol{t}$ незнаемо было (1670 Там само); вколо (1670 II 200) «навколо»; напрочь (Даль II 465) тощо. Пор. сучасні російські вдоволь (довольно), вкратце (краткий, кратко), завсегда, задаром, издревле, надовго (долгий, долго), назавтра, навечно, посейчас та ін.

Продовжується творення відприслівникових адвербативів і в білоруській мові: внизу, внизь, унизъ (1458-1459 ГСБМ III 62); Стодола великая ... вколо сажнь осмнадиать (1586 III 306), пор. вколо, вколь, вколь (1586 III 306) «навколо», коло (1663 XV 212) «те саме»; (завсегда, завсегды, завседы (1577 X 140, 141); задосить (1631 201) «досить, достатньо, доволі»; чомуж ем8так примовлете а замало важите (поч. XVII X 284) «мало, небагато», пор. сучасні білоруські заўсёдыл/заўсягды, задарма/задаром, задоуга, ззамаладу, надоўга, назауттра, навечна, наглуха напрайду, посейчас тощо.

$\mathrm{У}$ російській мові часто в постприйменниковій позиції виступали 


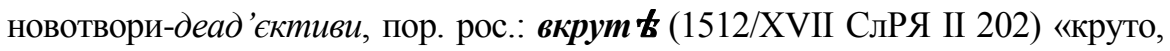
різким поворотом» від крутой; сила вся наша вышла и вмаль и ввелики (1514 II 27); вкось (1589 II 201); вкоротк $\boldsymbol{k}$ (1625 II 201) «коротко, швидко, скоро»; вдушевн с слово божие самь в всть (1672 II 42); впусте (1672 СловСиб 23) «поза господарським використанням»;Федка Шакловитый $y$ нихъ великихъ государей вв њдом $\boldsymbol{\xi}$ (1690 СлРЯ II 27) «бути відомим», пор.

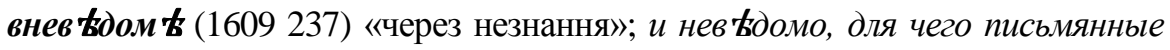
версты объявились внепольн ъ (1691 238) «не повністю»; вбуйне бамкирцы меня сгоняют (1696 26) «діючи свавільно»; A которые были вузелень - те хлебы на полю косили косами и кормят скотишко своя (1731 СловСиб 25); врямь, впрямъ, впрямо (Даль I 262) та ін.

Такі факти документуються й у пам'ятках білоруської мови: замала был есми во вслком зль (поч. XVI ГСБМ Х 284) «змалку» співвідносне 3 малий; абы гкрунт гдрьски впорожне не ваковаль (1578 IV 234); внове (1615 66) «недавно»; якось впродце и синачекъ его ... до св \$тлици увойдеть (1636 246); вновъ (1637 234) «знов» тощо, пор. сучасні сn'яну, здуру і т. ін.

Як і в українській, у російській мові документується багато прислівників, утворених від іменника 3 прийменником, де в ролі іменника виступає девербатив: даютъ взаймы денги (1551/XVII СлРЯ II 141); вкрадц (вкратц ()) (XVI II 201) «крадькома» від красти(сь) 3 відтворенням давнього [д]; без опасу (1607 СловСиб 9) «не боячись»; ө poccыnь (1657-1658 24) «в різні боки»; он ... взаперт ' нигд $\mathbf{k}$ не сид $\mathbf{k} л \mathbf{b}$ (1664 СлРЯ II 141); Торговые люди покупную свою всякую скотину ... перегнивали вбродъ и вплавъ (1688 II 26); без утыху (1745 СловСиб 164) «безперервно»; внагиб (1737 20) «зігнувши, пригнувши»; он принялся смеяться взахохот (СРНГ IV 238); взахватку, взахлес (Там само); впопад (Даль I 260) «до речі»; впригарь (261) «3 пригаром»; впроблеск (Там само) «мигцем» та багато інших. Такі самі деривати маємо в білоруській мові, пор. сучасні ўброд, упрытык, наўздагон, спросонку, уперамешк, упрысядкі, враз валочку та ін.

Ідентичні процеси в різних східнослов'янських мовах мають свої особливості. В українській мові постприйменникові девербативи та деад'єктиви - це звичайно нульсуфіксальні утворення, зрідка - деривати 3 суфіксом -ок, у російській та білоруській мовах значна частина цих утворень має нульовий суфікс i нульове закінчення, при цьому фінальний приголосний пом'якшується (вновь, вщирь, вкривь, впрямь, врознь/врозь, порознь), частина утворень у всіх трьох мовах має закінчення (яке стає суфіксом) у залежності від запрограмованої синтаксичної конструкції (здалеку, знову, подалі, свисока, сызнова, сдуру, смолоду, навеселе, наготове, наравне, накрепко, нарасхват, наглухо, спьяну, поровну, вполне, заживо, засветло). Поряд із наведеними фіналями в російських та білоруських 
постприйменникових компонентах часто зберігається прикметникова форма, чого немає в мові українській (рос. вхолостую, вчистую, зачастую, напропалую, вплотную, впрямую, врассьпную; блр. уррассіпную, ўхаластую, напрапалую, уххаластую, ушчыльную тощо) та суфікс -ок (насикосок) і -ка (навитяжку, вразвалочку, вперемішку, вприпрыжку, вприсядку).

Наведені міркування дають підставу стверджувати, що провідним способом творення моделей обставинних прислівників в східнослов'янських мовах є адвербіалізація прийменниково-іменникових конструкцій, другим компонентом яких $\epsilon$ «реальні» субстантиви та прислівники, що виступають у ролі іменників, або спеціально створені для цього субстантиви дієслівного чи прикметникового походження. На формування цих моделей, таким чином, вирішальний вплив справив розвиток синтаксичного ладу мов східних слов’ян.

\section{Перелік умовних скорочень використаних джерел}

АЖ Актова книга Житомирського уряду кінця XVI ст. (1582-1588рр.) / Підгот. до вид. М. К. Бойчук. - К. : Наук. думка, 1965. - 191 с.

АО Акти села Одрехови / Упоряд. І. М. Керницький, А. О. Купчинський. - К. : Наук. думка, 1970. - 260 с.

Apx Архангельский областной словарь. Вып. III (В-Вёсновой). Под ред. О. Г. Гецовой. - М. : Изд-во Моск. ун-та, 1983. - 160 с.

БерЛекс Лексикон словенороський Памви Беринди / Підгот. тексту і вступ. стаття В. В. Німчука : Надрук. з вид. 1627 р. фотомех. способом. - К. : Вид-во АН УРСР, 1961. - XL, $272 \mathrm{c.}$

Гетьм Ділова документація Гетьманщини XVIII ст. : Зб. документів / Упор., автор передмови та комент. В. Й. Горобець. - К. : Наук. думка,1993. - 392 с.

Гр Словарь української мови / Зібр. ред. журн. «Киев, старина». Упорядкував, 3 дод. власн. матеріалу, Б. Грінченко. - К., 1907-1909. - Т. 1-4.

Грам Граматика слов'янська І. Ужевича / Підгот. до друку І. К. Білодід, Є. М. Кудрицький. - К. : Наук. думка, 1970. - 40c.+86c. Передмова XXVI. Переклад, примітки, покажчик слів і граматичних форм, бібліографія. -113 с.

ГСБМ Гістарычны слоўнік беларускай мовы. - Мінск : Навука і техніка, 1983, 1984, 1990, 2001. - T. III, IV, X, XX.

Даль Даль В. Толковый словарь живаго великорускаго языка. Т. I-II, Спб.-М. : 1880.

Деркач Деркач Б. А. Перекладна українська повість XVII-XVIII ст. - К. : Вид-во АН УРСР, 1960. - $272 \mathrm{c.}$

Д3 Слово Даниила Заточника по редакциям XII и XIII вв. и их переделкам / Подгот. к печати Н. Н. Зарубин. - Л. : Изд-во АН СССР, 1932. - XVI, 166 с. XIII ил.

ДНМ Ділова і народнорозмовна мова XVIII ст. : (Матер. сотенних канцел. і ратуш Лівобереж. України) / Підгот. до вид. В. А. Передрієнко. - К. : Наук. думка, 1976. $-416 \mathrm{c}$.

ЛексЗиз «Лексис Лаврентія Зизанія» // Лексис Лаврентія Зизанія Синоніма славеноросская / Підгот. текстів пам'яток і вступ. ст. В. В. Німчука. - К. : Наук. думка, 1964. - С. 23-89.

ИФ Мещерский Н. А. История иудейской войны Иосифа Флавия в древнерусском переводе. - М. : Изд-во АН СССР, 1958. - 578 с.

IB Величковський І. Твори. - К. : Наук. думка, 1972. - 191 с.

듀. І. Білоусенко, 2013. 
ІлСл Слово о закон' и благодати // Молдаван А.М. «Слово о законе и благодати» Илариона. - К. : Наук. думка, 1984. - С. 78-196.

КП Абрамович Д. Києво-Печерський патерик. Репринтне видання. -К. : Час, $1991-280$ с.

КЛ «Книга Лъчєбн[а] XVIII ст. / Підгот. до вид. В. А. Передрієнко. - К. : Наук. думка, 1984. - С. 17-91.

ЛВел Величко С. Сказаніє о войнһ козацкой зъ поляками. - К. : Українська академія наук, 1926. - 275 с.

ЛГВ Галицько-Волинський літопис // Полное собрание русских летописей. Т. 2. Ипатьевская летопись. - М. : Изд-во вост. литературы, 1962. - С. 715-938.

Лис Лисенко П. С. Словник поліських говорів. - К. : Наук. думка, 1974. - 270 с.

ЛК Київський літопис // Полное собрание русских летописей. Т. 2. Ипатьевская летопись. - М. : Изд-во вост. литературы, 1962. - С. 384-707.

ЛО Лькарства Фписа(нъ)іє, которимы бє(з) мє(ди)ка в дому вслкъ поратоватсл можєть //Лікарські та господарські порадники XVIII ст. / Підгот. до вид. В. А. Передрієнко. - К. : Наук. думка, 1984. - С. 17-91.

ЛСам Летопись Самовидца по новооткрытым спискам с приложением трех малороссийских хроник. - К., 1873. - 469 с.

Нос Носович И. И. Словарь бһлорусскаго нарһчия. - Спб., 1870 ч. I-II.

Негрич Негрич М. Скарби гуцульського говору : Березови́. - Львів, 2008. - 224 с.

O

П

ПВЛ Повість временних літ за Лаврентіївським списком // Полное собрание

Онишкевич М. Г. Словник бойківських говірок. - К. : Наук. думка, 1984. - Ч. 1-2.

Грамоти XVI ст. / Упоряд., вступ. стаття, комент. і словники-покажчики М. М. Пещак. - К. : Наук. думка, 1974. - 255 с. русских летописей. Т. І. Лаврентьевская и Суздальская летопись по академическому списку. - М. : Изд-во вост. литературы, 1962. - С. 1-286.

ПР Правда русская / Тексты подгот. к печати В. П. Любимов, Н. Ф. Лавров, М. Н. Тихомиров и др. ; Под ред. Б. Д. Грекова. - М.-Л. : Изд-во АН СССР, 1940. - Т. 1. -505 с.

P Южнорусские грамоты. Собр. В. Розовым. - К. : Изд. отд. русского языка и словесности Академіи наукъ, 1917. - 75 с.

Рус Українські грамоти XV ст. / Підгот. тексту, вступна стаття і комент. В. М. Русанівського. - К. : Наук. думка, 1965. - 163 с.

СДЯ Словарь древнерусского языка (XI-XIV вв.) / Гл. ред. Р. И. Аванесов. - М. : Русский язык, 1988-1991. - Т. 1-4.

СИ Собраніе историческое // Летопись Самовидца по новооткрытым спискам с приложением трех малороссийских хроник. - К., 1873. - С. 320-378.

Син Синоніма славеноросская // Лексис Лаврентія Зизанія. Синоніма славеноросская / Підгот. текстів пам'яток і вступ. статті В. В. Німчука. - К. : Наук. думка, 1964. - С. 91-172.

СловСибСловарь русской народно-диалектной речи в Сибири XVII - П. пол. XVIII в. Новосибирск : Наука, 1991. - 181 с.

СлРЯ Словарь русского языка ХІ-XVII вв.-М. : Наука, 1975, 1977. - Вып. II, IV, 1975, 1977.

СРНГ Словарь русских народных говоров. - Вып. I, IV, XXI. - М.-Л., 1965, 1969, 1986.

ССУМ Словник староукраїнської мови XIV-XV ст. : в 2 т.- К. : Наук. думка, 19771978. - Т. 1-2.

УВ Устав князя Володимира Святославича // Древнерусские княжеские уставы XI-XV вв. / Изд. подгот. Я. Н. Шилов. - М. : Наука, 1976. - С. 22-24.

УП Українська поезія. Кінець XVI - поч. XVII ст. / Упоряд. В. П. Колосова, В. I. Крекотень. - К. : Наук. думка, 1978. - 432 с. 


\begin{tabular}{|c|c|}
\hline $\mathbf{X A}$ & $\begin{array}{l}\text { Книги врємєны и Фбразны Геюрги мниха // Истрин В. И. Хроника Георгия } \\
\text { Амартола в древнем славянорусском переводе. Т. І. Текст. Пг., 1920. - } 612 \text { с. }\end{array}$ \\
\hline ХД & $\begin{array}{l}\text { Житье и хожденье Данила Русьскыя земли игумена, 1106-1108. Текст } \\
\text { воспроизведен по древнейшему списку XV века. - Спб., 1896. - } 79 \text { с. }\end{array}$ \\
\hline Яв & $\begin{array}{l}\text { Яворницький Д. Словник української мови. Т. 1. А-К. - Катеринослав } \\
\text { Слово, 1920. }-412 \text { с. }\end{array}$ \\
\hline ЯМ & $\begin{array}{l}\text { Дневник генерального подскарбия Якова Марковича (1717-1734 гг.) / Под. } \\
\text { ред. А. Лазаревского. - К., 1983-1987. - Ч. І-ІІІ. - } 418 \text { с. }\end{array}$ \\
\hline H & Т. С. Янкова. Діялектны слоўнік Лоеўшчины. - Мінск : Навука і тэхніка, 1982. - 432 с. \\
\hline
\end{tabular}

\section{Лiтература}

1.Бевзенко С. П. Історична морфологія української мови : Нариси із словозміни i словотвору / С. П. Бевзенко. - Ужгород : Закарпатське обласне вид-во, 1960. - 416 с.

2. Борковский В. И. Историческая грамматика русского языка / В. И. Борковский, П. С. Кузнецов. - М. : Изд-во АН СССР, 1963. - 512 с.

3. Вихованець I. Р. Студії про частини мови: Термінологічний аспект / І. Р. Вихованець // Українська термінологія і сучасність : зб. наук. праць. - К., 2005. Вип. VI. - С. 3-9.

4. Гумецька Л. Л. Нарис словотворчої системи української актової мови XIV-XV ст. / Л. Л. Гумецька. - К. : Вид-во АН УРСР, 1958. - 298 с.

5. Даценко І. Б. Історія формування прислівників місця української мови : дис. ... канд. філол. наук : 10.02.01/ І. Б. Даценко. - К., 2007. - 215 с.

6. Довгая Т. М. Адвербиализация в современном украинском литературном языке : автореф. дис. ... канд. филол. наук / Т. М. Довгая. - Ужгород, 1970. - 20 с.

7. Иванов В. В. Историческая грамматика русского языка / В. В Иванов. - М. : Просвещение, 1990. - 400 с.

8. Коневецкий А. К. История наречий в русском языке : автореф. дис. ... д-ра филол. наук / А. К. Коневецкий. - Саратов, 1977. - 44 с.

9. Ломтев Т. П. Из истории русского синтаксиса / Т. П. Ломтев. - М. : Учпедгиз, 1954. $-256 \mathrm{c}$.

10. Мазанько И. Ф. Заметки об образовании наречий в древнерусском языке / И. Ф. Мазанько // Вопросы языкознания. - 1976. - №5. - С. 111-125.

11. Мазанько И. Ф. Образование наречий в русском языке XI-XVIII веке (на материале лексико-семантических групп со значением пространственной ориентации) : автореф. дис. ... канд. филол. наук / И. Ф. Мазанько. - М., 1977. - 24 с.

12. Мазанько И.Ф. ШУИЙ и ЛњВЫЙ в языке письменных памятников эпохи XI-XIV вв. (О лексике пространственной ориентации в древнерусском языке) / И.Ф. Мазанько. - Изв. АН СССР : Сер. лит. и яз. Т. ХХХІІІ. - Вып.5. - 1976 - С. 477-480.

13. Мейе А. Общеславянский язык / А. М. Мейе. - М. : Изд-во иностр. л-ры, $1951-491$ с.

14. Німчук В. В. Синтаксичні функції прийменників / В. В. Німчук // Історія української мови. Синтаксис / Арполенко Г. П., Грищенко А. П., Німчук В. В. та ін. - К. : Наук. думка, 1983. - С. 131-230.

15. Пауль Г. Принципы истории языка / Г. Пауль. - М. : Изд-во иностр. лит., 1960. - 500 с.

16. Русанівський В. М. Префіксальний словотвір / Г. М. Гнатюк, К. Г. Городенська, А. П. Грищенко, Н. Ф. Клименко, І. І. Ковалик, Л. О. Родніна, В. М. Русанівський, Л. А. Юрчук // Словотвір сучасної української літературної мови. - К. : Наук. думка, 1979. - С. 228-283.

17. Ткаченко В. А. Наречие // Коломиец В. Т., Линник Т. Г., Лукинова Т. Б. та ін. Историческая типология славянских языков / В. А. Ткаченко. - К. : Наук. думка, 1986. C. $120-137$. 
18. Уздыган И. М. Отадъективные наречия в украинском языке XIV-XVII вв. (словообразовательная структура) : автореф. дис. ... канд. филол. наук / И. М. Уздыган. К., 1975. - 24 c.

19. Федорук-Галкина Е. М. Наречие в современном русском языке / Е. М. ФедорукГалкина. - М., 1939. - 156 с.

20. Чапля І. К. Прислівники в українській мові / І. К. Чапля. - Харків : Вид-во Харків. ун-ту, 1960. - 134 с.

21. Шерех Ю. Нарис сучасної української літературної мови / Ю. Шерех. Мюнхен : Молоде життя, 1951. - 402 с.

22. Щербатюк Г. Х. Просте речення / Г. Х. Щербатюк // Арполенко Г. П., Грищенко А. П., Німчук В. В. та ін. Історія української мови. Синтаксис. - К. : Наук. думка, 1983. - С. 11-130.

23. Языковая номинация (Виды наименований). - М. : Наука, 1977. - 359 с.

24. Янович Е. И. Наречие в истории русского языка : Генезис и функционирование основных морфологических типов производных наречий / Е. И. Янович. - Минск : Изд-во БГУ, 1978. - 144 с.

25. Doritsch A. Gebrauch der altbulgarischen Adverbia / A. Doritsch - Leipzig, 1910. - 113 s. 